\title{
The earliest true bugs and aphids from the Middle Triassic of France (Hemiptera)
}

\author{
Аревнейшие клопы и тли из среднего триаса Франщии \\ (Hemiptera)
}

\author{
D.E. Shcherbakov \\ A.E. Щербаков
}

Borissiak Paleontological Institute, Russian Academy of Sciences, Profsoyuznaya ul. 123, 117647 Moscow, Russia. E-mail: dshh@narod.ru Палеонтологический институт им. А.А. Борисяка РАН, Профсоюзная ул. 123, 117647 Москва, Россия.

KEY WORDS: true bugs, aphids, Heteroptera, Nepomorpha, Naucoridae, Potamocoridae, Helotrephidae, Triassocoridae, Homoptera, Aphidomorpha, Palaeoaphidoidea, Creaphididae, fossil, first records, Mesozoic, Triassic, Anisian, France, Vosges.

КЛЮЧЕВЫЕ СЛОВА: клопы, тли, Heteroptera, Nepomorpha, Naucoridae, Potamocoridae, Helotrephidae, Triassocoridae, Homoptera, Aphidomorpha, Palaeoaphidoidea, Creaphididae, ископаемые, первые находки, мезозой, триас, анизий, Франция, Вогезы.

ABSTRACT. The earliest fossil records of true bugs and aphids are described from the earliest Middle Triassic of France. The water bug Arlecoris louisi gen. et sp.n. (Arlecorinae subfam.n.) is assigned to Naucoroidea and provisionally included into the Triassic family Triassocoridae. The aphid Leaphis prima gen. et sp.n. (Leaphidinae subfam.n.) is placed into the Triassic family Creaphididae; subfamily Triassoaphidinae stat.n. is assigned to this family as well.

РЕЗЮМЕ. Из низов среднего триаса Франции описаны древнейшие ископаемые находки клопов и тлей. Водный клоп Arlecoris louisi gen. et sp.n. (Arlecorinae subfam.n.) отнесён к Naucoroidea и предварительно включён в триасовое семейство Triassocoridae. Тля Leaphis prima gen. et sp.n. (Leaphidinae subfam.n.) отнесена к триасовому семейству Creaphididae, в которое включено также подсемейство Triassoaphidinae stat.n.

\section{Introduction}

The earliest Middle Triassic (early Anisian) biota known from the Grès à Voltzia Formation of the northern Vosges Mountains, France, contains a rich assemblage of insects [Gall, 1971; Gall \& Grauvogel-Stamm, 2005; Gall et al., 2006], including diverse Hemiptera [Shcherbakov, 2008c]. These fossils are housed in the private collection of Louis Grauvogel, Strasbourg. During my visit to France in 1998 I discovered among this material the earliest fossil representatives of true bugs and aphids (reported by Shcherbakov \& Popov [2002]). These finds are described below.
The water bug is provisionally assigned to the Triassic family Triassocoridae - insufficiently known, but apparently allied to Naucoridae [Shcherbakov \& Popov, 2002]. All observable characters of this bug, including a single nymphal abdominal scent gland with paired openings at the posterior margin of the 3rd tergite, agree with Naucoroidea; it shows certain similarities to some Naucoridae Ambrysinae, Potamocoridae, and also Helotrephidae Neotrephinae (Notonectoidea), thus supporting the opinion of China [1940] that proto-Helotrephidae arose from proto-Naucoroidea. The aphid is attributable to the Triassic family Creaphididae in the broad sense. The next oldest true bugs and aphids are known from the Madygen Formation of Kyrgyzstan, dated Ladinian-Carnian (or rather Ladinian, based on indirect evidence) [Shcherbakov \& Wegierek, 1991; Shcherbakov, 2008b]. The Ladinian Dracaphis Hong et al., 2009, singled out into Dracaphididae by Hong et al. [2009], falls within Naibiidae, the family assigned to Coccomorpha [Shcherbakov, 2007] (systematic affinities of these forms will be discussed separately).

Taxonomy

$$
\begin{gathered}
\text { Nepomorpha } \\
\text { Naucoroidea Fallén, } 1814 \\
\text { ?Triassocoridae Tillyard, } 1922 \\
\text { Arlecorinae Shcherbakov, subfam.n. } \\
\text { TYPE GENUS. Arlecoris Shcherbakov, gen.n. } \\
\text { DIAGNOSIS. Small, dorsoventrally flattened aquatic }
\end{gathered}
$$$$
\text { TYPE GENUS. Arlecoris Shcherbakov, gen.n. }
$$
bugs. Hemelytra with dark confluent stripes on pale background, broad, widest before midlength, gradually narrowed distally, acutely rounded at apex, only slightly overlapping in repose, leathery, without conspicuous punctures, apparently 
covered with adpressed hairs. Membrane poorly separated from corium. Precostal carina wide near base. Costal fracture long, oblique, arched distad, proximally close to apex of medial fracture; venation of corium and membrane not discernible. Clavus relatively long, occupying half hemelytron length; claval commissure as long as scutellar margin; claval suture continued beyond apex of clavus; Pcu arched posteriad (for vein nomenclature, see Shcherbakov [2008a]). Mesoscutellum short, forming rounded right angle at apex. Scar of nymphal abdominal scent gland retained as pair of small, close-set, dark spots near posterior margin of 3rd tergite. Connexivum of $5-7$ th abdominal segments exposed, fringed with short setae; angles of segments not produced. Ventral laterotergites not separated. Female 6th and 7 th sternites with clearly delimited, paler posteromedian areas, that of 7 th sternite prolonged caudad as subgenital plate. Ovipositor large, longer than $1 / 3$ abdomen, with 3 rd valvulae and sclerotized rods along 1 st valvulae.

COMPOSITION. Type genus.

COMPARISON. Differs from the previously known naucoroids and other Nepomorpha by the combination of the distinctive hemelytron shape and colour pattern, oblique costal fracture, moderately long claval commissure, short mesoscutellum, large ovipositor, and close-set openings of nymphal abdominal scent gland on 3rd tergite. In the hemelytron shape and length of claval commissure the new taxon is similar to the modern South American Ambrysus Stål, 1862 subg. Melloiella De Carlo, 1935 (Naucoridae: Ambrysinae), but in the latter the costal fracture and claval suture are absent, the mesoscutellum is longer, and the angles of posterior abdominal segments are produced. In the structure of female abdomen it resembles the modern South and Central American Potamocoridae, but these latter are distinct in the hemelytron structure. The colour pattern of hemelytra is similar to that of the modern South American Neotrephes China, 1936 (Helotrephidae: Neotrephinae), but in the latter the dorsum is well convex, the claval commissure is shorter, and hemelytra are coarsely punctate.

Arlecoris Shcherbakov, gen.n.

DIAGNOSIS. As for subfamily.

COMPOSITION. Type species.

ETYMOLOGY. From the Italian Arlecchino (Harlequin, a comic servant character wearing a distinctive motley costume) and Greek koris (bug); gender masculine.

\section{Arlecoris louisi Shcherbakov, sp.n.}

MATERIAL. Holotype: female 9172 \pm (part \& counterpart; forebody and legs not visible) — Vilsberg, Moselle; paratype: right hemelytron 5058/5059 (part \& counterpart) - Arzviller, Moselle; early Anisian.

DESCRIPTION (Figs 1-5). Hemelytron $3.2 \mathrm{~mm}$ long, $1.6 \mathrm{~mm}$ wide (2.0:1). Costal margin nearly straight proximally. Median fracture occupying $1 / 3$ hemelytron length; costal fracture entering margin at about $1 / 2$ hemelytron length. Hemelytron pale with broad dark median stripe on corium, dark stripe distal to costal fracture, continued around apical margin of membrane and forming an angle touching median stripe, and dark stripe posterior to Pcu. Female ca. $5.5 \mathrm{~mm}$ long (4.2 $\mathrm{mm}$ as preserved). No trace of hindwings discernible. Female abdomen $3.0 \mathrm{~mm}$ long, $2.8 \mathrm{~mm}$ wide, widest at 4 th segment; posteromedian area of 6th sternite subtriangular with posterior margin convex; that of 7 th sternite more projecting caudad, rather diamond-shaped, concealing basal part of ovipositor. Mesoscutellum, metahorax and abdomen dark. Head, prothorax, and legs unknown.
ETYMOLOGY. After Louis Grauvogel, who collected most of the insect specimens known from the Triassic of Vosges.

$$
\text { Aphidomorpha }
$$

Palaeoaphidoidea Richards, 1966

\section{Creaphididae Shcherbakov et Wegierek, 1991, s.1.}

DIAGNOSIS (revised). Pterostigma elongate to linear, not reaching wing apex. RP (=RS) separating near base of pterostigma or from its distal part. $\mathrm{M}$ with three branches; distal part of $\mathrm{M}$ stem projecting onto $\mathrm{Sc}+\mathrm{R}$ far from $\mathrm{CuA}$ base. CuA stem shorter than $\mathrm{CuA} 2$. Claval furrow and claval vein developed.

COMPOSITION. Three subfamilies: Leaphidinae subfam.n., Creaphidinae Shcherbakov et Wegierek, 1991, stat.n., Triassoaphidinae Heie, 1999, stat.n.

REMARKS. The family Palaeoaphididae has been raised to the superfamily level by Shcherbakov \& Popov [2002: 145]. Creaphididae are known from forewings only.

\section{Leaphidinae Shcherbakov, subfam.n.}

TYPE GENUS. Leaphis Shcherbakov, gen.n.

DIAGNOSIS. Small aphids. Pterostigma rather broad, its posterior margin convex. RP separating before pterostigma. $\mathrm{M} 2$ subequal to $\mathrm{M} 1+2, \mathrm{M} 3+4$ much longer than $\mathrm{M}$ stem. $\mathrm{CuA}$ stem nearly as long as $\mathrm{CuA} 2$.

COMPOSITION. Type genus.

COMPARISON. Distinct from the nominate subfamily in the shape of pterostigma, shorter $\mathrm{M}$ stem, and longer $\mathrm{CuA}$ stem.

REMARKS. The salient difference in the shape of pterostigma between Creaphis and Leaphis gen.n. is almost the same as the difference in this trait between Lizeriinae and most other Drepanosiphidae. Another difference between these genera, in the relative length of the $\mathrm{CuA}$ stem, is paralleled by the variation described in Ellinaphidinae (Palaeoaphididae) [Kania \& Wegierek, 2008].

\section{Leaphis Shcherbakov, gen.n.}

TYPE SPECIES. Leaphis prima Shcherbakov, sp.n.

DIAGNOSIS. As for subfamily.

COMPOSITION. Type species.

ETYMOLOGY. After Dr. Lea Grauvogel-Stamm, paleobotanist, and genus Aphis; gender feminine.

\section{Leaphis prima Shcherbakov, sp.n.}

MATERIAL. Holotype: right forewing 5916/5917 (part \& counterpart) - Arzviller, Moselle; early Anisian.

DESCRIPTION (Figs 6-7). Forewing ca. $2.0 \mathrm{~mm}$ long (1.7 $\mathrm{mm}$ as preserved), $0.8 \mathrm{~mm}$ wide (ca. 2.5:1). Costal margin straight (slightly convex at pterostigma); costal area markedly narrowed distally. Sc+R slightly bent at separation of $\mathrm{CuA}$. Pterostigma moderately long (longer than $1 / 4$ wing length, longer than $\mathrm{Sc}+\mathrm{R}$ after separation of $\mathrm{CuA}$ ) and relatively wide (ca. 4:1), tapered in distal $1 / 4$, with posterior margin well convex. RP separating just before pterostigma, closely parallel to its margin proximally, gradually diverging from it and curved distally. Basal 1/3 of M stem not discernible. $M$ stem and $M 1+2$ close to RP. M forked level with pterostigma base, $\mathrm{M} 1+2$ forked level with pterostigma apex; M2 slightly longer than M1+2; M3+4 curved distally, twice as long as $\mathrm{M}$ stem. $\mathrm{CuA} 1$ not weaker than $\mathrm{CuA}-\mathrm{CuA} 2$. $\mathrm{CuA} 2$ slightly longer than $\mathrm{CuA}$ stem. $\mathrm{RP}$ and all $\mathrm{M}$ and $\mathrm{CuA}$ veins appear equally thick, $\mathrm{Sc}+\mathrm{R}$ stem much thicker. Pterostigma and veins dark, membrane pale.

ETYMOLOGY. From the Latin primus (first). 

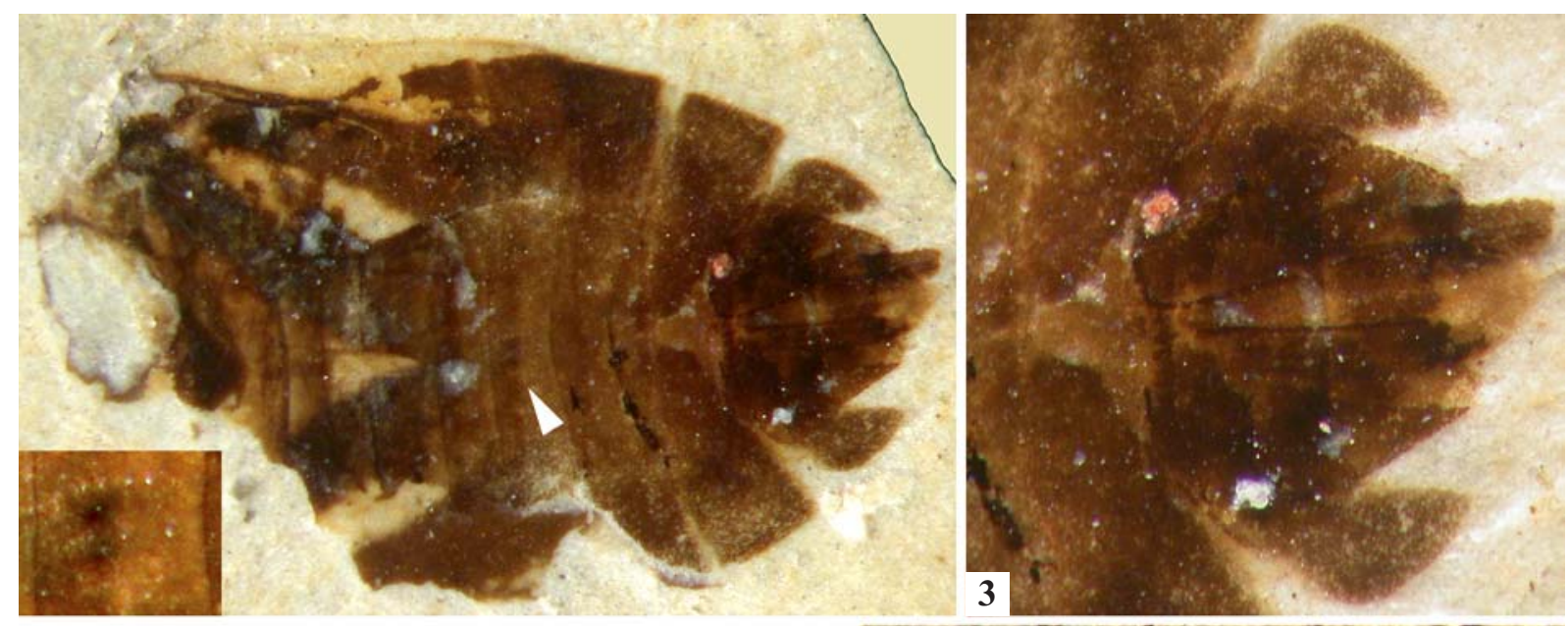

1
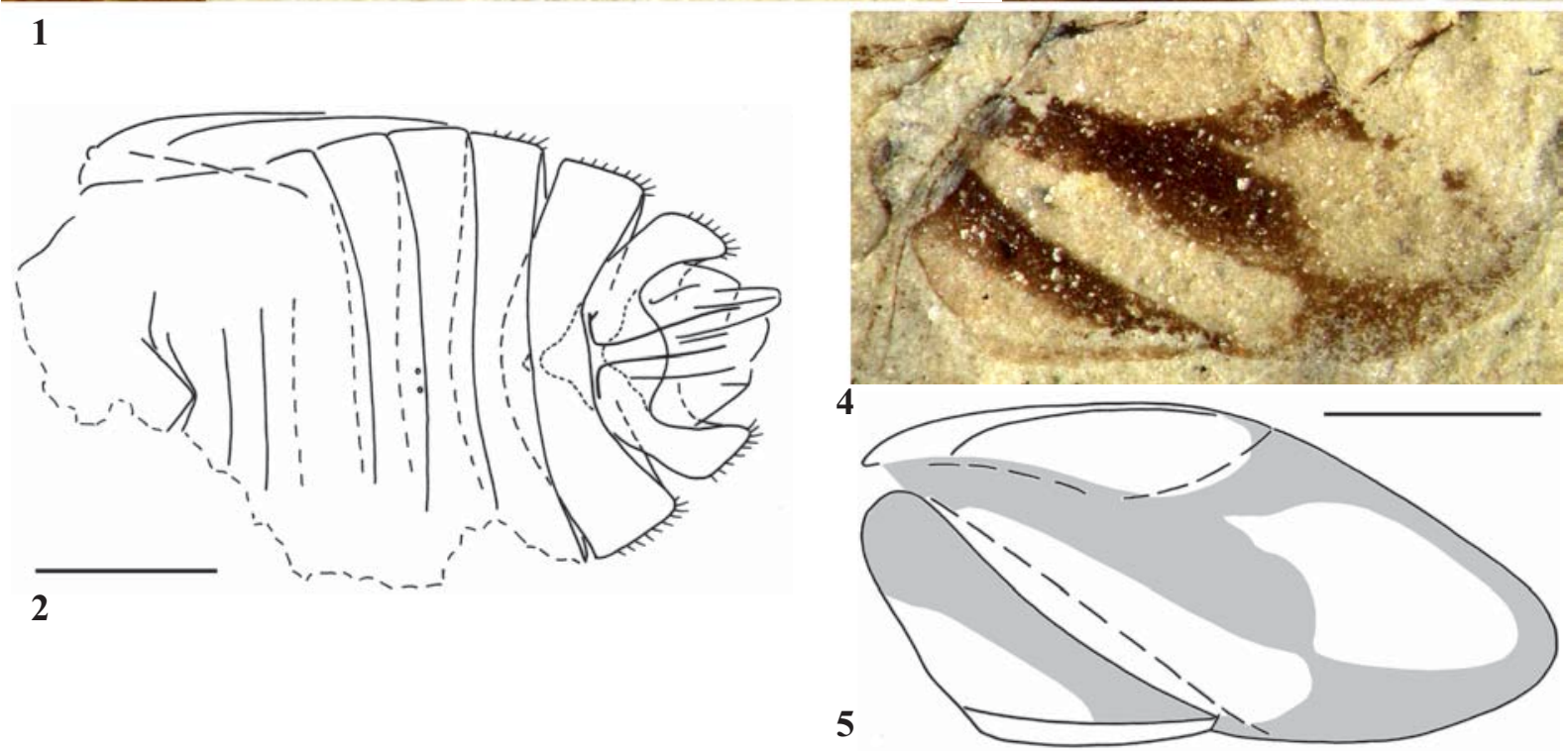

Figs 1-5. Arlecoris louisi gen. et sp.n., earliest Middle Triassic, northern Vosges Mountains, France: 1-3 - holotype female 9172, counterpart (dorsal structures are better visible in thorax and anterior abdomen, ventral structures in posterior abdomen): 1-2 - habitus (note scar of nymphal abdominal scent gland — arrow and inset); 3 - apex of abdomen; 4-5 - paratype right hemelytron 5058/5059: 4 counterpart 5058 (mirrored); 5 - venation and colour pattern (partly reconstructed after holotype). Scale bar $1 \mathrm{~mm}$ in all figures.

Рис. 1-5. Arlecoris louisi gen. et sp.n., низы среднего триаса, северные Вогезы, Франция: 1-3 - самка, голотип 9172, обратный отпечаток (в области груди и основания брюшка лучше видны дорзальные структуры, ближе к вершине брюшка - вентральные): 1 2 - общий вид (виден след нимфальной брюшной пахучей железы - стрелка и врезка); 3 - вершина брюшка; 4-5 - правое надкрылье, паратип 5058/5059: 4 - обратный отпечаток 5058 (зеркально перевернут); 5 - жилкование и темный рисунок (частично реконструировано по голотипу). Масштабная линейка - 1 мм (здесь и далее).
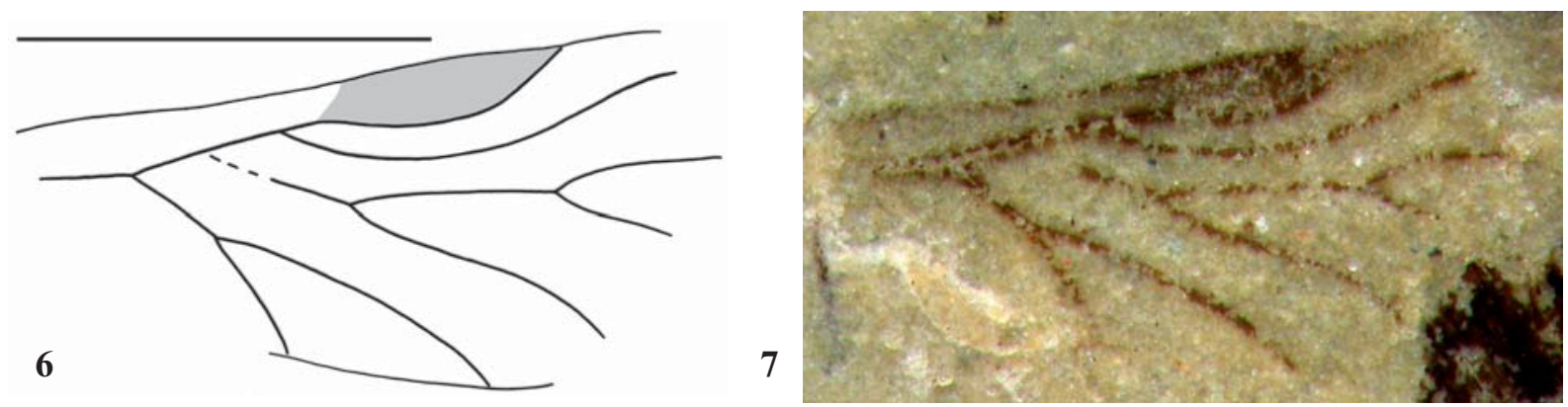

Figs 6-7. Leaphis prima gen. et sp.n., holotype forewing 5916/5917, earliest Middle Triassic, northern Vosges Mountains, France: 6 venation; 7 - part 5916.

Рис. 6-7. Leaphis prima gen. et sp.n., переднее крыло, голотип 5916/5917, низы среднего триаса, северные Вогезы, Франция: 6 жилкование; 7 - прямой отпечаток 5916. 
Creaphidinae Shcherbakov et Wegierek, 1991, stat.n.

DIAGNOSIS. Medium-sized aphids. Pterostigma narrowly triangular, its posterior margin straight. RP separating at pterostigma base. M2 subequal to $\mathrm{M} 1+2, \mathrm{M} 3+4$ subequal to $\mathrm{M}$ stem. $\mathrm{CuA}$ stem much shorter than $\mathrm{CuA} 2$.

COMPOSITION. Creaphis Shcherbakov et Wegierek, 1991.

Triassoaphidinae Heie, 1999, stat.n.

DIAGNOSIS (revised). Large aphids. Pterostigma linear, its posterior margin straight. RP separating from distal part of pterostigma or (see Remarks below) before pterostigma. $\mathrm{M} 2$ much longer than $\mathrm{M} 1+2, \mathrm{M} 3+4$ much longer than $\mathrm{M}$ stem. $\mathrm{CuA}$ stem much shorter than $\mathrm{CuA} 2$.

COMPOSITION. Triassoaphis Evans, 1956.

REMARKS. Triassoaphididae has been created as a family quite distinct from Creaphididae [Heie, 1999]. However, some undescribed Triassic forms are similar to Triassoaphis in many essential characters, except for RP originating just before the pterostigma (not from its distal part), thus much narrowing the gap between this genus and Creaphis.

ACKNOWLEDGEMENTS. I am grateful to Dr. Lea Grauvogel-Stamm and Dr. Francine Marchal-Papier (Strasbourg) for their help and hospitality during our visits to France, and to Dr. Yuri Popov and Dr. Roman Rakitov (Moscow) for valuable discussion. The research was supported by ESF and RFBR (projects \#\# 07-04-01158, 10 04-01713).

\section{References}

China W.E. 1940. New South American Helotrephidae (Hemiptera-Heteroptera) // Annals and Magazine of Natural History. Ser.11. Vol.5. P.106-126.

Gall J.-C. 1971. Faunes et paysages du Grès à Voltzia du Nord des Vosges. Essai paléoécologique sur le Buntsandstein supérieur //
Mémoires du Service de la Carte géologique d'Alsace et de Lorraine. No.34. P.1-318.

Gall J.-C., Grauvogel-Stamm L. 2005. The early Middle Triassic 'Grès à Voltzia' Formation of eastern France: a model of environmental refugium // Comptes Rendus Palevol. Vol.4. P. 637-652.

Gall J.-C., Grauvogel-Stamm L., Papier F. 2006. Archives de grès. L'Alsace il y a 240 millions d'années. Communauté de Communes du Pays de La Petite Pierre: La Petite Pierre. 90 $\mathrm{pp}$

Heie O.E. 1999. Aphids of the past (Hemiptera, Sternorrhyncha) // Proceedings of the First International Palaeoentomological Conference, AMBA projects AM/PFICM98/1.99. Bratislava. P.49-55.

Hong Y., Zhang Z., Guo X., Heie O.E. 2009. A new species representing the oldest aphid (Hemiptera, Aphidomorpha) from the Middle Triassic of China // Journal of Paleontology. Vol.83. P.826-831.

Kania I., Wegierek P. 2008. Palaeoaphididae (Hemiptera, Sternorrhyncha) from Lower Cretaceous Baissa deposits. Morphology and classification. Instytut Systematyki i Ewolucji Zwierzat, Polska Akademia Nauk: Kraków. 135 pp.

Shcherbakov D.E. 2007. Extinct four-winged precoccids and the ancestry of scale insects and aphids (Hemiptera) // Russian Entomological Journal. Vol.16. P.47-62.

Shcherbakov D.E. 2008a. Mesozoic Velocipedinae (Nabidae s.1.) and Ceresopseidae (Reduvioidea), with notes on the phylogeny of Cimicomorpha (Heteroptera) // Russian Entomological Journal. 2007. Vol.16. P.401-414

Shcherbakov D.E. 2008b. Madygen, Triassic Lagerstätte number one, before and after Sharov // Alavesia. Vol.2. P.113-124.

Shcherbakov D.E. 2008c. Insect recovery after the Permian/ Triassic crisis // Alavesia. Vol.2. P.125-131.

Shcherbakov D.E., Popov Yu.A. 2002. Order Hemiptera Linné, 1758. The bugs, cicadas, plantlice, scale insects, etc. // A.P. Rasnitsyn, D.L.J. Quicke (eds.). History of Insects. Kluwer: Dordrecht. P.143-157.

Shcherbakov D.E., Wegierek P. 1991. Creaphididae, a new and the oldest aphid family from the Triassic of Middle Asia // Psyche. Vol.98. P.81-85. 